The Egyptian Journal of Hospital Medicine (Oct 2012) Vol., 49: 555- 572

\title{
LOW BIRTH WEIGHTS: I- MATERNAL RISK FACTORS - A HOSPITAL- BASED STUDY IN CAIRO CITY, EGYPT
}

\author{
ESSAM A. EL-MOSELHY*, IBRAHIM SAAD NADA**, \\ HAMED O. KHALIFA*, and KHADRA I. MOHAMMAD*** \\ Community Medicine*, Industrial Health \& Occupational Medicine**, and Obstetrics \& \\ Gynecology***, Faculty of Medicine, Al-Azhar University
}

\begin{abstract}
Background: Low birth weight (LBW) is an important public health problem. The problem is prevalent world-wide and has negative impacts. So, its prevention is a major challenge.
\end{abstract}

Objective: To determine maternal risk factors of LBW in Cairo city.

Design: A case-control, hospital-based, study design.

Subjects: Mothers of 270 LBW neonates were recruited in this study. A control group of mothers of an equal number of normal birth weight (NBW) neonates was chosen.

Methods: The mothers of LBW and NBW neonates were interviewed using a specially designed questionnaire. All mothers had been subjected to full examinations. The neonates were weighted and examined after labor.

Results: Low education, unskilled occupation, and husband unavailability are significant sociodemographic risk factors of $\mathrm{LBW}$; OR=1.75, 1.62, and 2.21, respectively. Mother's height $(\leq 145 \mathrm{~cm})$, BMI $\left(<18 \mathrm{~kg} / \mathrm{m}^{2}\right)$, history of previous abortion, and maternal family history of LBW are significant personal characteristic risk factors of $\mathrm{LBW}$; $\mathrm{OR}=3.26,5.11,3.27$, and 3.23, respectively. The significant obstetric risk factors are congenital malformations, weight gain during pregnancy $\leq 6 \mathrm{~kg}$, multiple gestations, bleeding at first/second trimester, presence of complications during delivery, gestation age $<37$ weeks, and birth spacing $<2$ years; OR $=13.61$, $7.61,7.15,5.92,3.93,3.17$, and 2.84, respectively. Absence of antenatal care, inadequate healthy diet intake, physical hard activities, exposure to tobacco smoke, and living nearby heavy air pollution are significant health care behavioral and life-style risk factors of LBW; OR=2.49, 2.72, 2.96, 3.64, and 4.8, respectively. Anemia, hypertension, and history of recurrent chronic/specific infections are significant medical risk factors of LBW; OR=2.68, 4.35 and 4.84, respectively. Anorexia nervosa/stress, oligo/polyhydramnios, and gestational hypertension are significant gynecological/obstetric conditions risk factors; $\mathrm{OR}=3.53,3.32,3.23$, and 3.36, respectively. Lastly, the most important risk factors of LBW as weighted by partial F-test are multiple gestations, neonate congenital malformations, weight gain during pregnancy $\leq 6 \mathrm{~kg}$, maternal BMI $<18 \mathrm{~kg} / \mathrm{m}^{2}$, gestation age $<37$ weeks, and mother's weight at early pregnancy $\leq 45 \mathrm{~kg}$, ( F test $=2.9$, $2.7,2.6,2.3,2.2$, and 2.2 , respectively).

Recommendations: There is a need for improving the quality and utilization of ANC services, nutritional education, birth spacing, and avoidance exposure to tobacco smoke. Also, increasing promotion of reproductive health services in relation to safe motherhood at community level in order to reduce risk factors of LBW is needed. Lastly, further population based studies are needed in different areas in Egypt.

Key words: Low birth weight, pregnancy, maternal risk factors, Egypt.

Corresponding author; Dr. Essam A. El-Moselhy, Professor of Epidemiology and Community Medicine, Al-Azhar Faculty of Medicine, E-mail: dr_elmoslhy@ hotmail.com 


\section{Introduction}

Growth and development of the fetus are complex. They influenced by genetic, epigenetic, maternal maturity, and environmental factors (Wu et al., 2006). All these factors affect the size and functional capacity of the placenta, uteroplacental transfer of nutrients and oxygen from mother to fetus, conceptus nutrient availability, fetal endocrine milieu, and metabolic pathways. Optimal fetal growth is essential for perinatal survival (Gluckman and Hanson, 2007).

World-wide, more than 20 million infants are born each year weighing less than 2500 grams $(\mathrm{g})$, accounting for $17.0 \%$ of all births in the developing world; a percent more than double that found in developed countries, $7.0 \%$ (UNICEF and WHO, 2004). The prevalence of low birth weight (LBW) varies between and within geographical regions (WHO, 1980). Prevalence of LBW babies in India is $21.5 \%$ (NFHS-3 India, 2007). However, some studies in India reported higher figures; $23.8 \%$ (Sharma et al., 2009) and $26.8 \%$ (Mumbare et al., 2012). In Latin America the percent of LBW infants is $10.1 \%$ whereas in Africa, it is estimated at $14.0 \%$ (WHO, 1980). However, in Tanzania a study reported a proportion of LBW neonates among term babies ranging from $56.0 \%$ to $62.0 \%$ (Klingenberg $\boldsymbol{e t}$. al., 2003). Also, in Tanzania a study reported a prevalence of LBW is $13.6 \%$ (Julius, 2008). The prevalence of LBW in North America and Europe is $6.8 \%$ and $6.5 \%$, respectively (Villar and Belizan, 1982). In Egypt, pervalence of LBW babies is suggested to be $2.1 \%$ of all deliveries in Cairo city. Further, prevalence of LBW is found to be $8.8 \%$ of unfavorable pregnancy outcomes (El-Houseinie et al., 1994). Moreover, pervalence of LBW is found to be $7.9 \%$ in Zagazig city, Egypt. While, prevalence of preterm labor (baby born <37 weeks of gestation) is $5.7 \%$ (Ragab et al., 2001). More than fourth $(26.4 \%)$ of unfavorable pregnancy outcomes was LBW in Zagazig city (El-Badawy et al., 2004).
Low birth weight is a multifactorial phenomenon (Deshmukh et al., 1998). Many maternal and fetal factors are found significantly to be associated with the low birth weight (Singh et al., 2009). LBW can be caused either by premature delivery (short gestation) or by fetal growth restriction (Julius, 2008). Known factors for preterm labor and fetal growth restriction that are associated with LBW include low maternal food intake, hard physical work during pregnancy, and illness, especially infections (Renqvist et al., 1994 and Klingenberg et al., 2003). Also, studies suggested that cigarette smoking, genetic and environmental factors can cause LBW (Bang et al., 1999). Further, short maternal stature, very young age, high parity, and close birth spacing; all are associated risk factors (UNAIDS, 1999 and Verma \& Das, 2003). Many of these risk factors are prevalent among disadvantaged communities (Julius, 2008). So, LBW is common among mothers with low educational levels and who had a hard occupation (Julius, 2008). Also, there is a significant association between low socioeconomic status and LBWs (NFHS-3 India, 2007; Sharma et al., 2009; Jafari et al., 2010; Viengsakhone et al., 2010 and Mumbare et al., 2012).

Further, low birth weight has many impacts on infant morbidity and mortality. These impacts include jaundice (ARCCOP Australia, 1996), and neonatal infections (Hillier and Holmes, 1999).

\section{STUDY OBJECTIVES}

\section{I- Ultimate Objective:}

Improve quality of the health of the mothers, fetuses, infants, and children in Egypt.

\section{II- Immediate Objectives:}

To investigate the role of sociodemographic, life-style, health care behavioral, and clinical risk factors of LBW among pregnant women attending Al-Zhraa Hospital, Al-Azhar University. 


\section{SUBJECTS AND METHODS I- Study Questions:}

Is there maternal sociodemographic, life-style, health care behavioral, and/or clinical risk factors for LBW?

\section{II- Study Design:}

A case-control, hospital based study design was used to investigate the current research problem.

\section{III- Study Setting:}

This study was conducted in the Obstetrics and Gynecology Department in Al-Zhraa Hospital, Al-Azhar University.

\section{IV- Study Sample:}

According to sample size equation the sample was $246 \mathrm{LBW}$ neonates, and to guard against sample size bias we increased the sample by $10.0 \%$ to be 270 LBW neonates. So, mothers of the 270 LBW neonates delivered in the Obstetrics Department in Al-Zhraa Hospital, Al-Azhar University were included in the study. For each LBW neonate a neonate with normal birth weight (NBW) was chosen randomly. So, a control group of mothers of the 270 NBW neonates was recruited.

Inclusion criteria were LBW neonates, exact duration of amenorrhea was known; the first day of the last menstrual period reported by the mother to calculate the gestational age at the time of delivery, or mothers may have had estimates of gestational age derived by ultrasound measurement made at antenatal care (ANC), mother's willing to participate in the study, and suitable matched control was available. If any of the above criteria was not fulfilled then the neonate was not included as a case in the study.

\section{V- Ethical Considerations:}

The purpose of the study and procedures to be performed were explained to all mothers, confidentiality was assured, and an oral consent to participate in the study was taken accordingly.

VI- Study Tools and Methods:

1- Interview questionnaire: A specially designed questionnaire included various variables related to topic of the study was used to collect data. The mothers with LBW and NBW neonates were submitted to an interview. A pilot study was conducted to test the feasibility and validity of the questionnaire; the necessary corrections were done.

2- Clinical examinations: Both general and local physical examinations were done for mothers with LBW and NBW neonates. Also, anthropometric measurements of mothers; heights and weights were done. Weight $(\mathrm{kg})$ was measured while women wear light outer garment and without shoes. Height (cm) was measured in standing position. Weight gain during pregnancy was calculated by subtracting weight of the mother before pregnancy or $\leq 12$ weeks of gestation from her weight at labor. Body mass index (BMI) was calculated as weight (before pregnancy or $\leq 12$ weeks of gestation) divided by height squared $\left(\mathrm{kg} / \mathrm{m}^{2}\right)$.

3- Laboratory investigations: Laboratory examinations were done for all mothers with LBW and NBW neonates. Midstream urine samples were taken at time of interviewing the mothers; after labor, for microscopic examination to detect cases of urinary tract infections. Also, maternal venous blood samples were taken from all mothers to determine hemoglobin $(\mathrm{Hb})$ concentration levels $(\mathrm{g} / \mathrm{dL})$.

\section{VII- Statistical Analysis:}

Odds ratio (OR) with 95\% confidence interval (CI) or exact confidence limits (ECL) was used as test of significance. Also, stepwise regression analysis was applied to find out the weight of risk factors and effect of the potential confounders. In stepwise regression; adjusted partial $F$ test was used as sgnificangce level.

\section{Results}

Table (1) shows distribution of mother's with LBW neonates and mothers with NBW neonates according to sociodemographic risk factors. Low educational status is significant risk factor of LBW; OR=1.75, 95\% CI: 1.19-2.57. Also, unskilled occupation is significant risk factor; $\quad \mathrm{OR}=1.62, \quad 95 \% \quad \mathrm{CI}: \quad 1.07-2.47$. Collectively, low social level is significant 
risk factor; $\mathrm{OR}=1.56,95 \% \mathrm{CI}$ : 1.07-2.27. Further, husband non availability, which means social support, is the higher significant risk factor; $\mathrm{OR}=2.21,95 \% \mathrm{CI}$ : 1.38-3.54. On the other hand, high social level and husband availability are significant protective factors; $\mathrm{OR}=0.54,95 \% \mathrm{CI}$ : 0.30 0.96 and $\mathrm{OR}=0.45,95 \%$ CI: $0.28-0.73$, respectively.

Table (2) illustrates distribution of mother's with LBW neonates and mothers with NBW neonates according to personal characteristic risk factors. Low mother's age at marriage ( $\leq 18$ years) is significant risk factor for $\mathrm{LBW}$; $\mathrm{OR}=2.14$, 95\% CI: 1.233.72. Further, mother's height $(\leq 145 \mathrm{~cm})$, mother's weight before/at early pregnancy $(\leq 45 \mathrm{~kg})$, mother's weight at delivery $(\leq 55$ $\mathrm{kg})$, mother's BMI $\left(<18\right.$ and $\left.18-<22 \mathrm{~kg} / \mathrm{m}^{2}\right)$, and maternal family history of LBW are significant risk factors for $\mathrm{LBW}$; $\mathrm{OR}=3.26$, 95\% CI: $1.86-5.72, \mathrm{OR}=2.38,95 \%$ CI: $1.32-$ 4.31, $\mathrm{OR}=2.72, \quad 95 \% \quad \mathrm{CI}: \quad 1.49-5.01$, $\mathrm{OR}=5.11,95 \% \mathrm{ECL}: 1.61-21.26, \mathrm{OR}=2.71$, 95\% CI: $1.3-5.71$, and $\mathrm{OR}=3.23,95 \% \mathrm{CI}$ : 2.01-5.19, respectively. Also, history of consanguinity is significant risk factor for LBW; OR=3.15, 95\% CI: 1.76-5.68. Lastly, history of previous abortion is significant risk factor for $\mathrm{LBW}$; $\mathrm{OR}=3.27$, 95\% CI: 1.54-7.05.

Table (3) clears distribution of mother's with LBW neonates and mothers with NBW neonates according to obstetric risk factors. The highest significant risk factors for LBW are congenital malformations, weight gain during pregnancy $\leq 6 \mathrm{~kg}$, multiple gestations and bleeding at first or second trimester; $\mathrm{OR}=13.61$, 95\% ECL: 2.01-500.36, OR= 7.61, 95\% CI: $4.9-11.88$, OR=7.15, 95\% CI: $3.49-14.98$ and $\mathrm{OR}=5.92$, 95\% CI: 3.3310.64, respectively. Further, presence of complications during delivery and gestation age ( $<37$ weeks) are significant risk factors for LBW; OR=3.93, 95\% CI: 2.04-7.67 and $\mathrm{OR}=3.17$, 95\% CI: 1.81-5.59, respectively. Also, low mother's age at gestation $(<20$ years) and low birth spacing ( $<2$ years) are significant risk factors for $\mathrm{LBW}$; $\mathrm{OR}=2.13$, 95\% CI: $1.21-3.77$ and $\mathrm{OR}=2.84,95 \% \mathrm{CI}$ :
1.59-5.08, respectively. Lastly, female infant gender is significant risk factor; $\mathrm{OR}=1.86$, 95\% CI: $1.27-2.37$.

Table (4) depicts distribution of mother's with LBW neonates and mothers with NBW neonates according to life-style and behavioral risk factors. Absence of antenatal care utilization, and irregular ANC utilization are significant risk factors for LBW; OR=2.49, 95\% CI: $1.68-3.69$ and $\mathrm{OR}=1.73$, 95\% CI: 1.04-2.86, respectively. Further, no multivitamin intake, inadequate rest times, and inadequate healthy diet intake are significant risk factors for LBW; $\mathrm{OR}=2.04,95 \%$ CI: $1.39-3.00, \quad \mathrm{OR}=2.55$, 95\% CI: $1.64-3.97$, and $\mathrm{OR}=2.72,95 \% \mathrm{CI}$ : 1.84-4.01, respectively. Lastly, physical hard activities, exposure to tobacco smoke, and living nearby heavy air environmental pollution are significant risk factors for LBW; OR=2.96, 95\% CI: 1.93-4.55, OR= 3.64, 95\% CI: 2.41-5.53, and $\mathrm{OR}=4.8,95 \%$ CI: 3.09-7.48, respectively.

Table (5) clarifies distribution of mother's with LBW neonates and mothers with NBW neonates according to medical, gynecological and obstetric risk factors. Anemia $(\mathrm{Hb}<10 \mathrm{~g} / \mathrm{dL})$, hypertension, history of recurrent chronic/specific infections, and urinary tract infections are significant medical risk factors for LBW; OR=2.68, 95\% CI: $1.82-3.95, \quad O R=4.35$, 95\% ECL: 1.50-15.29, OR=4.84, 95\% CI: 2.15-11.19, and $\quad \mathrm{OR}=3.14, \quad 95 \% \quad \mathrm{CI}:$ 1.63-6.11, respectively. Also, anorexia nervosa/stress, oligo/polyhydramnios, vaginal infection/ vaginosis, gestational hypertension, and $\mathrm{PE} /$ eclampsia are significant gynecological and obstetric conditions risk factors for LBW; $\mathrm{OR}=3.53$, 95\% ECL: 1.17-12.69, OR=3.32, 95\% CI: $1.42-7.92$, OR=3.23, 95\% CI: $1.42-$ 7.92, OR=2.95, 95\% CI: $1.39-6.34, \mathrm{OR}=$ $3.36,95 \%$ CI: $1.56-7.39$, and $\mathrm{OR}=2.68,95 \%$ CI: 1.12-6.56, respectively.

Table (6) represents stepwise regression analysis of factors affecting low birth weight. The most important risk factors of LBW as weighted by partial F-test are muliple gestations, neonate congenital malformations, weight gain during pregnancy $\leq 6 \mathrm{~kg}$, maternal malnutrition 
(severe underweight: BMI $<18 \mathrm{~kg} / \mathrm{m}^{2}$ ), gestation age $<37$ weeks, mother's weight before/at early pregnancy $\leq 45 \mathrm{~kg}$, maternal height $<145 \mathrm{~cm}$, exposure to tobacco smoke, no ANC utilization, bleeding at first or second trimester, PE/eclampsia, and hypertension (partial $\mathrm{F}$ test $=2.9,2.7,2.6$, $2.3,2.2,2.2,2.1,1.8,1.7,1.5,1.5$, and 1.4 , respectively).

\section{Discussion}

One of the goals of the 1990 World Summit for Children was to reduce the prevalence of low birth weight to less than $10.0 \%$ by the year 2000 (Boerma et al., 1996 and Podja \& Kelly, 2000). This goal, however, remains a formidable challenge to date. So, it is encouraging that the international public health community has begun to increase its attention toward the four million infants who die each year and the many more that survive with a diminished quality of life. LBW is a reasonable well defined problem caused by factors that are potentially modifiable and the costs of preventing them are well within reach, even in developing countries (Julius, 2008).

In this study we showed low maternal education is significant risk factor for LBW. Low maternal education is associated with delivery of LBW infants (Mumbare et al., 2012). This is expected as low education leads to low health consciousness, lower nutritional status and low antenatal attendance, leading to the increased risk of LBW babies (Mann et al., 1974). The proportion of LBW deliveries significantly decreased as maternal education level increased $(\chi 2=35.22$, $P<0.01)$. Mothers without formal education were about 4 times more likely to give birth to LBW neonates than those who had attained higher education. There was a linear decrease in low birth weights of newborns as fraternal educational level increased $\left(\chi^{2}\right.$ for linear trend $=42.7, P<0.01)$. The risk of primary education and none education is significant; $\mathrm{OR}=1.74,95 \% \mathrm{CI}: 1.35-2.26$ and $\quad \mathrm{OR}=3.59, \quad 95 \% \quad \mathrm{CI}: \quad 2.18-5.92$, respectively (Julius, 2008). Further, maternal education $<5$ and 5-11 years of schooling was significant risk factor for LBW; OR=4.22, 95\% CI: $1.12-17.20$ and $\mathrm{OR}=2.95$, 95\% CI: 1.19-10.76; respectively (Sharma et al., 2009).

In the present study we reported hard and low maternal occupation is significant risk factor for LBW. This finding agrees with Kramer (1987). A statistically significant difference in LBW as a result of variations in the types of maternal occupations $(\chi 2=25, P<0.01)$ was observed. Women who were peasants had the highest proportion $(17.5 \%)$ of LBW of all the maternal occupations recorded with twice the likelihood of delivering LBW neonates than housewives $(\mathrm{OR}=1.99,95 \% \mathrm{CI}$ : 1.36 2.91). Maternal occupation could not lead to a sound deduction as they were not scientifically classified and unclear. A housewife could at the same time be a peasant, businesswoman or unemployed. Many combinations were probable in fraternal occupations thus the factor could not reflect any socioeconomic effect on birth weight. On the other hand, housewife is protective factor for LBW outcomes (Julius, 2008). Also, highest proportion of LBW observed among mothers who were peasants could be attributed to the strenuous work they were subjected to in the field. Farming, which involves prolonged standing and other rigorous undertakings could be the most probable reason for the increased risk for preterm birth among such women (Henriksen, 1995), thus increased chances of LBW. In pastoralists, high proportions of LBWs were associated with the observations that women spend most part of the day standing while looking after cattle or squatting during milking thus straining their bodies and possibly get little time for resting (Tema, 2006).

Our study illustrated low socioeconomic status is significant risk factor for LBW neonates. This finding is consistent with many other studies as NFHS-3 India (2007); Sharma et al. (2009); Jafari et al. (2010); Viengsakhone et al. (2010) and Mumbare et al. (2012). LBW was comparatively higher among 
babies born to mothers who were belonging to family with income <Rs. 2000 per capita compared with >Rs. 2000 per capita. But, the risk was insignificant (Sharma et al., 2009). Also, the higher risk for $L B W$ babies in women who lived single as compared with married ones reflects the importance of socioeconomic support on maternal health and birth outcomes. Being married and housewife were protective factors for LBW outcomes. This could be a result of socioeconomic support they get from their husbands such that they were not under such stresses (Julius, 2008). Also, we observed rural residence is insignificant risk factor for LBW. This might be due to rural residence, low level of education and environmental pollution. Julius (2008) reported out of 2075 pregnant women, $322(15.51 \%)$ gave birth of LBW in rural areas compared with $153(11.29 \%)$ LBW in urban areas.

In the present study, we showed maternal height $(\leq 145 \mathrm{~cm})$ is significant risk factor for LBW. This result is accordance with Kramer (1987) in his meta-analysis, and many studies from developing countries Ferraz et al. (1990); Mavalankar et al. (1992); Fikree et al. (1994); Pelletier et al. (1995); Deshmukh et al. (1998); UNAIDS (1999); Verma \& Das (2003); Acharya et al. (2004); Jafari et al. (2010) and Mumbare et al. (2012); they have identified maternal height $(<145 \mathrm{~cm})$ as a potential risk factor for LBW. Also, conditional logistic regression analysis showed height $\leq 145 \mathrm{~cm}$ is significant risk factor associated with LBW $\quad(\mathrm{OR}=4.13, \quad 95 \% \quad \mathrm{CI}: \quad 2.04-8.37)$ (Mumbare et al., 2012).

In this study, we observed low maternal weight $(\leq 45 \mathrm{~kg})$, before or early at first trimester of pregnancy, and weight before delivery $\leq 55 \mathrm{~kg}$ are significant risk factors for LBW. Mothers' underweight gave rise to the higher proportions of LBW babies. The likelihood of these women to deliver LBW babies concurred with findings from a study done among pregnant women in East Java (Kusin et al., 1994 and Mathule et al., 2005). So, maternal underweight is risk factor for LBW, prevalence $=26.7 \%$ and $\mathrm{RR}=2.39$, 95\% CI:
1.29-4.44 (Hammad and El-Gilany, 2008). Also, this result is concur with Kramer (1987) in his meta-analysis, and other studies from many developing countries Ferraz et al. (1990); Mavalankar et al. (1992); Fikree et al. (1994); Pelletier et al. (1995); Acharya et al. (2004); and Jafari et al. (2010); they have identified maternal weight $(<45 \mathrm{~kg})$ as a potential risk factor for LBW. Also, Sharma et al. (2009) noticed pre-pregnancy weight $<45 \quad \mathrm{~kg}$ was significant risk factor for $\mathrm{LBW}$; OR=5.60, 95\% CI: 1.63-19.7. Further, studies have found increased incidence of preterm labor and LBW in underweight pregnant women (Naeye, 1990 and Spinillo et al., 1998). Another studies have showed the importance of low maternal weight on the risk of perinatal outcomes; maternal anemia, intrauterine growth restrection (IUGR), preterm labor, and LBW (Ehernberg et al., 2003; Bhattacharya et al., 2007 and Sahu et al., 2007). While, Mumbare et al. (2012); have identified maternal weight before delivery $\leq 55 \mathrm{~kg}(\mathrm{OR}=4.81,95 \% \mathrm{CI}$ : 2.53 9.15) as potential risk factor for LBW.

Collectively, LBW is significantly associated with low maternal BMI as a result of low body weight in relation to height. This could be attributed to limited maternal weight gain particularly during the third trimester. This could mainly be due to poor maternal nutrition around and during pregnancy adversely affect fetal and neonatal outcomes (Kind et al., 2006). Also, among underweight mothers (BMI=18-22), prevalence of LBW was $15.45 \%$ compared with $84.55 \%$ among NBW infants. The highest prevalence $(17.14 \%)$ of LBW infants was observed in mothers who were malnourished (BMI <18) compared with $82.86 \%$ among NBW infants. Generally the proportions decreased as the anthropometric measurement increased and the interclass differences were statistically significant $(\chi 2=25, \quad P<0.01) \quad$ (Julius, 2008). Malnourished mothers gave rise to the higher proportions of LBW babies (Kusin $\boldsymbol{e t}$ al., 1994 and Mathule et al., 2005). So, poorly nourished mother is significant risk 
factor for $\mathrm{LBW}$; OR=5.60, 95\% CI: 1.6319.7 (Sharma et al., 2009).

In this study, we noticed consanguinity is significant risk factors for LBW. Consanguinity is common in developing countries due to social, cultural and economic reasons including traditions. Our result is concurring with Badshah $\boldsymbol{e t}$ al. (2008); they found an independent effect of consanguinity on SGA. This observation could also be as a result of small statures of some parents thus affecting the neonatal phenotype (Julius, 2008). Also, the association of parental body size with neonatal phenotype was observed; Leary $\boldsymbol{e t}$ al. (2006) cleared mother-baby relationships were similar in most populations.

In the present study, we observed history of previous abortion is significant risk factor for LBW. Our result concurs with Badshah et al. (2008); they showed previous abortion is associated independently with SGA babies. Abortion affects maternal health through anaemia and haemorrhage, and pregnancy outcomes through LBW and short gestation.

In the current study we cleared young maternal age at gestation $(<20$ years) is significant risk factor for LBW. This result is concurring with Mann et al. (1974) and Viengsakhone $\boldsymbol{e t}$ al. (2010), they have shown young maternal age is significant risk factor of LBW. Further, proportion of LBW is comparatively higher among babies born to mothers who were below 20 years of age (50.0\%) compared with all other age groups (Sharma et al., 2009). Also, very young age is an associated factor (UNAIDS, 1999 and Verma \& Das, 2003). Further, the next highest adjusted OR effect in explaining the incidence of LBW was for maternal age $<20$ years (Badshah et al., 2008). On the other hand, Julius (2008) showed prevalence's of LBW in the 20-35, 36-50, and 13-19 years age groups were $14.57 \%, 12.84 \%$, and $11.96 \%$, respectively compared with $85.43 \%, 87.16 \%$, and $88.04 \%$ of NBW, respectively with insignificant statistically differences. She said although 20-35 years age group is the recommended reproductive age group, it was responsible for the highest proportion of LBW infants. Also, Badshah et al. (2008) and Sharma et al. (2009) found maternal age is insignificant risk factor for LBW. Recently, Mumbare et al. (2012) has not identified maternal age as a significant risk factor for LBW babies. Also, Mavalankar et al. (1992) and Fikree et al, (1994) in Pakistan and Acharya et al. (2004) in India have not identified maternal age as significant risk factor for LBW.

Our finding multi parity $(\geq 3)$ is insignificant risk factor for LBW. This result is accordance with Mumbare et al. (2012); they have found parity as an insignificant risk factor for LBW babies. Also, Mavalankar et al. (1992) and Fikree et al, (1994) in Pakistan and Acharya et al. (2004) in India have not identified parity as significant risk factor for LBW babies. On the other hand, UNAIDS (1999) and Verma \& Das (2003); have shown high parity is associated factor for LBW. Also, Mann et al. (1974) and Viengsakhone et al. (2010) have shown parity is significant risk factor of LBW. Prevalence of LBW was comparatively lower in primigravida mothers $(18.4 \%)$ as compared with multigravida mothers $(29.5 \%)$. Birth order 2-3 was significant risk compared to birth order 1 (Sharma et al., 2009).

We illustrated low birth spacing $(<2$ years) is risk factor for LBW. Close birth spacing is factor associated with LBW (UNAIDS, 1999 and Verma \& Das, 2003). Birth spacing <36 months is associated with delivery of LBW infants (Mumbare et al., 2012).

In this study, we showed multiple gestation is significant risk factor for LBW. Twins' gestations affected significantly the LBW outcome as was the case in Meagher (1993); ARCCOP Australia (1996); Lowry et al. (1998); Hillier and Holmes (1999) and Sharma et al. (2009). Multiple gestation represents about $25.0 \%$ of all LBW infants and $28.0 \%$ of the very (V) LBW infants. Although multiples represent only 1 in 34 births, they account for 1 in 5 preterm births, 1 in 4 LBW births, and 1 in 3.5 VLBW births (Statistics Canada, 2004). The average birth weight for each 
multiple birth baby is approximately $2500 \mathrm{~g}$ for twins, $1800 \mathrm{~g}$ for triplets, and $1400 \mathrm{~g}$ for quadruplets (Cunningham et al., 2010).

In the current study we cleared bleeding at first or second trimester is significant risk factor for LBW. This result is in line with Julius (2008); she showed maternal bleeding wad significant risk factor for LBW; OR=4.93, 95\% CI: 2.87-8.45.

As we expected, LBW deliveries are higher in babies whose gestation ages were $<37$ weeks. Low gestation age was the variable that had the highest association with LBW. The finding underlines the effect intrauterine growth restriction rather than prematurity, which is a common factor for LBW in developing countries (Julius, 2008). Also, this observation is in line with findings of Villar and Belizan (1982) in a study done in developing settings as compared to findings from developed regions of the world. Also, Julius (2008) found among 460 LBW babies, 418 $(90.87 \%)$ were preterm, gestation age $<37$ weeks. Premature deliveries were two times likely to result into $\mathrm{LBW}(\mathrm{OR}=2.03,95 \%$ CI: 1.46- 2.83). Further, the adjusted OR for gestational age showed the largest effect in explaining the incidence of LBW (Badshah et al., 2008).

In the current study, we noticed weight gain during pregnancy $\leq 6$ is significant risk factor for LBW. Pregnancy weight gain $\leq 6 \mathrm{~kg}$ is associated with delivery of LBW infants (Mumbare et al., 2012).

In this study, we reported infant female gender is significant risk factor for LBW. The prevalence of LBW was significantly higher in females $(15.7 \%)$ than in males $(12.1 \%)(\chi 2=9.26, P<0.01)$ (Julius, 2008).

In the current study, we illustrated the congenital malformations is significant risk factor for LBW. Congenital malformations are an important cause of LBW mortality and morbidity and may be found to account for a great percentage of LBW deaths, depending on the frequency of autopsy. Major neural tube malformations are more common among the lower socioeconomic groups, at extremes age and parity, and in female fetus. Major chromosomal aberrations constitute another group of congenital malformations that frequently lead to early death (Meagher, 1993). Our result is concur with ARCCOP Australia (1996); Wilkinson (1997) and Lowry et al. (1998) studies. Congenital malformations incidence nowadays, possibly because of awareness, is common.

In this study, intrapartum complications, such as placenta abruption and previa, are significant risk factor for LBW. This was the case in Meagher (1993); ARCCOP Australia (1996); Lowry et al. (1998); Hillier and Holmes (1999) and Sharma et al. (2009). Also, this concurs with the findings from a study done in Colorado, USA, which reported about half of all births complicated by abruption of placenta were LBW (Colorado Department of Public Health, 2002). Women with abruption placenta and placenta previa had the highest proportions of LBW babies of $50.0 \%$ and $45.0 \%$, respectively. On the other hand, lack of complications during delivery is protective factor for LBW (Julius, 2008).

In this study, we reported absence of antenatal care is significant risk factor for LBW. However most of mothers start attending ANC clinics in their sixth to seventh months of gestation (Ahmed and Behrman, 1990). Many diseases can be prevented by treatment before gestation or during ANC (Sharma et al., 2009). Pregnant women who did not attend ANC service had about a third $(28.6 \%)$ of their neonates in the LBW group compared with $13.8 \%$ of those who attended $(\mathrm{OR}=2.50$, 95\% CI: 1.34-4.69) (Julius, 2008). Also, Mumbare et al. (2012) cleared inadequate ANC was associated with delivery of LBW infants. Moreover, conditional logistic regression analysis showed that inadequate ANC is significant risk factor associated with LBW (OR=4.98, 95\% CI: 2.64-9.39).

In the current study, we illustrated physical hard activities, inadequate healthy diet, and inadequate rest times are significant risk factors for LBW. LBW was associated with the observations that women 
spend most part of the day standing while looking after cattle or squatting during milking thus straining their bodies and possibly get little time for resting (Henriksen, 1995 and Tema, 2006). So, factors for pre-term delivery and fetal growth retardation, which are associated with LBW, include low maternal food intake and hard physical work during pregnancy (Renqvist et al., 1994 and Klingenberg et al., 2003).

We observed maternal exposure to tobacco smoke is significant risk factor for LBW. Exposure to tobacco smoke is associated with delivery of LBW infants (Mumbare et al., 2012). All infants' born alive data $(n=4,115,494)$ in the U.S. in 1991 were analyzed. Infants born to smoked women had a lower average birth weight $($ mean $=3,145 \mathrm{~g}$; prevalence of $\mathrm{LBW}=11.4 \%$ ) than infants born to nonsmokers (mean=3,370g; prevalence of $\mathrm{LBW}=6.4 \%$ ) (Herna'ndez-Di'az et al., 2006). Also, risk of delivering LBW was 4.1 times high in women exposed to any tobacco product compared to those who were not exposed (Mumbare et al., 2012). Our finding is confirmatory to the findings of Deshmukh, et al. (1998); Gupta, et al. (2004) and Ward et al. (2007). Further, not only smoking that is widely accepted as an independent risk factor for LBW, but also tobacco chewing is a risk for LBW (Mumbare et al., 2012). On the other hand, both maternal and paternal smoking habits did not show any influence on birth weights (Julius, 2008).

In this study, we illustrated environmental air pollution is significant risk factor for LBW. This result concomitant with Lamadrid-Figueroa et al. (2007); they suggested maternal lead exposure during pregnancy is inversely related to fetal growth, as reflected by preterm labor and LBW. Also, Irgens et al. (1998) showed women occupationally exposed to lead were more likely to deliver a LBW infant than non exposed women. On the other hand, West et al. (1994) cleared the mean maternal blood lead was not significantly different $\quad(6.3 \pm 0.3 \quad$ vs. $7.6 \pm 1.2 \mu \mathrm{g} / \mathrm{dL}$, $\mathrm{p}=0.06$ ) between mothers who gave LBW infants and controls with NBW infants.

As regard medical conditions, we showed anemia is significant risk factor for LBW. Maternal anemia is associated with delivery of LBW infants. Presentation with anaemia was found to be significant independent factor for LBW (Badshah $\boldsymbol{e t}$ al., 2008). Anemia was found common among $143(52.2 \%)$ of mothers with LBW vs. $71(25.9 \%)$ of mothers with NBW (Mumbare et al., 2012). Also, studies have showed the importance of low maternal weight on the risk of maternal anemia and LBW (Ehernberg et al., 2003; Bhattacharya et al., 2007 and Sahu et al., 2007).

We reported maternal hypertension, gestational hypertension, pre-eclampsia (PE), and eclampsia are significant risk factors for LBW. Maternal hypertension is associated with delivery of LBW infants (Mumbare et al., 2012). Also, $P E$ is a disease that has great significance on the mother and infant (Roberts, 1998). Our results concur with Meagher (1993); ARCCOP Australia (1996); Lowry et al. (1998); Hillier \& Holmes (1999) and Sharma et al. (2009). In developed countries PE has a major effect on the fetus and neonate. Application of proper ANC and management has largely eliminated maternal mortality, at the cost of preterm delivery. About $10.0 \%$ of PE cases occur at a stage of gestation where delivery exchanges a sick fetus in uterus for a sick premature infant in the nursery (Goldenberg and Rouse, 1998). Also, PE has associated with a higher risk for IUGR (Report the Task Force ACOG/AAP, 2003). Hypertension and PE/eclampsia had the highest prevalence (46.7\%) among women who had LBW babies (Julius, 2008). The major cause of fetal compromise in PE is reduced uteroplacental perfusion (Lindheimer et al., 1999). $\mathrm{PE}$ is associated with a significant risk for unfavorable pregnancy outcome including preterm birth and LBW (El-Houseinie $\boldsymbol{e t}$ al., 1994 and Roberts, 1998). Also, hypertensive pregnant patients have 3-4 times more preterm 
deliveries than did the normotensive women (El-Houseinie et al., 1994). Infants of PE women were delivered earlier and, therefore, there was significant difference in birth weight of the neonates of $\mathrm{PE}$ patients compared to controls $(2.26 \pm 0.91$ vs. $3.22 \pm 0.41 \mathrm{Kg}, \mathrm{P}<0.001$ ) (Kolusari et al., 2008). As regard hyperemesis gravedarum, we it is significant risk factor for LBW. This may be due to low maternal appetite, and low diet intake and absorption. However, Julius (2008) didn't found a significant risk; $\mathrm{OR}=1.62$, 95\% CI: 0.85-3.08.

In the current study, we demonstrated female genital tract infections are significant risk factor for LBW. Female genital tract infections had been shown to be a risk factor for preterm labor, delivery of LBW neonates, and postpartum endometritis. These complications can be prevented by treatment of these infections before gestation or during ANC (Sharma $\boldsymbol{e t}$ al., 2009). Also, pregnant women who had history of recurrent chronic and/or specific infections were at increased risk of giving birth to LBW neonates, most probably due to low maternal appetite, good diet, immune system, and weight. Known factor for preterm delivery and fetal growth retardation, which is associated with LBW include illness, especially infections (Renqvist $\boldsymbol{e t}$ al., 1994 and Klingenberg et al., 2003).

\section{Conclusions and Recommendations}

Sociodemographic and personal differentials, ANC utilization, mother's health status, exposure to tobacco smoke, risky pregnancy, and major congenital malformations were detected as being risk factors for LBW. The findings of this study emphasizes the need for improving the quality and utilization of $\mathrm{ANC}$, nutritional education to improve the weight gain during pregnancy, birth spacing, avoidance exposure to tobacco smoke, and prevention and proper management of risk factors. So, it is important to identify risk factors of LBW in Egypt to deal with it by feasible intervention strategies to overcome the problem. The proplem of LBW in Egypt reflecting the likelihood of these neonates being born in poor socioeconomic conditions, where women are more susceptible to infections, poor diet, and more likely had hard physical work, even, during pregnancy. Also, it reflects a generational cycle of undernutrition, the consequences of which are passed to children from mothers. So, improvements in the health and socioeconomic status of women is urgent. Also, prevention and control of many risk factors such as genital and urinary tract infections are likely to reduce the incidence of LBW babies. Lastly, further population based studies are needed to determine prevalence of LBW in different areas in Egypt, to obtain a good understanding of its epidemiological risk factors, and to determine its impacts on the mother and her baby.

\section{References}

Acharya D, Nagraj K, Nair NS and Bhat HV (2004): Maternal determinants of intrauterine growth retardation: a case control study in Udupi District, Karnataka. Indian J Comm Med, 29: 181-3.

Ahmed E and Behrman T (1990): Factors and intervention associated with low birth weight. Available at http://www.bsetstart.org/ resources/ lbw aware/lbw rpt/lbw Chap2a.

ARCCOP Australia (Annual Report of Consultative Council on Obstetric and Pediatric) (1996): Incorporating the $35^{\text {th }}$ survey of LBW deaths in Victoria.

Badshah S, Mason L, McKelvie K, Payne $\mathbf{R}$ and Lisboa P JG (2008): Risk factors for low birth weight in the public-hospitals at Peshawar, NWFP-Pakistan. BMC Public Health, 8: 14-8.

Bang AT, Bang RA, Baitule SB, Reddy MH and Deshmukh MD (1999): Effect of home based neonatal care and management of sepsis on neonatal mortality: Field trial in India. Lancet, 354: 1955-61.

Bhattacharya S, Cambpell DM and Liston WA (2007): Effect of body mass index on pregnancy outcome in nalliparous women delivring singleton babies. BMC Public Health, 7: 168-72.

Boerma JT, Weinstein KI and Rutstein SO (1996): Data on birth weight in developing countries: Can surveys help? Bull WHO, 74: 209-16.

Colorado Department of Public Health (2000): Weighing in on solutions to the low birth 
weight problem in Colorado. Available at http://www.. cdphe. state. co. us/fc/ lbwreport.

Cunningham FG, Leveno KJ, Bloom SL, Hauth GC, Spong CU and Dwight JR (2010): Text book of Williams' obstetrics- Hypertensive disorder in pregnancy. 23th Ed, McGraw-Hill, New York.

Deshmukh JS, Motghare DD, Zodpey SP and Wadhva SK (1998): Low birth weight and associated maternal factors in an urban area. Indian Pediatr, 35: 33-6.

Ehernberg HM, Dierker LR, Milluizzi $C$ and Mercer BM (2003): Low maternal weight, failure to therive in pregnancy and adverse perinatal outcome. Am J Obet Gynecol, 189: 1726-30.

El-Badawy AA, Sherif NA, Ibraheem HE, Eltokhy HM and Ahmed SE (2004): Assessment of some factors affecting the outcomes of high pregnancy in Zagazig University hospitals, Egypt. Egypt J Comm Med, 22(2): 55-64.

El-Houseinie M, Salama EI, Radwan M, Hemeida SA, Sammour MB and Faris $R$ (1994): Development of a scoring system for the prediction of the unfavorable pregnancy outcome. Egypt J Comm Med, 12(1): 71-8.

Ferraz EM, Gray RH and Cunha TM (1990): Determinants of preterm delivery and intrauterine growth retardation in north-east Brazil. Int J Epidomiol, 19: 101-8.

Fikree FF and Berendes HW (1994): Risk factors for term intrauterine growth retardation: Community based study in Karachi. Bull WHO, 72: 581-7.

Gluckman PD and Hanson MA (2007): Developmental plasticity and human disease: Research directions. J Int Med, 261: 461-71.

Goldenberg RL and Rouse DJ (1998): Prevention of premature birth. N Engl J Med, 339: 313-20.

Gupta PC and Sreevidya S (2004): Smokeless tobacco use, birth weight, and gestational age: Population based prospective cohort study of 1217 women in Mumbai, India. BMJ, 328: 153840.

Hammad SM and El-Gilany A (2008): The effect of body mass index on prgnancy outomes. Egypt J Comm Med, 26(2): 15-26.

Henriksen T (1995): Factors and intervention associated with low birth weight. Available at http://www.bsetstart.org/resources/lbw aware/ lbwrpt/lbw Chap2a.html.

Herna'ndez-Di'az S, Schisterman EF and Herna'n MA (2006): The birth weight "paradox" uncovered? Am J Epidemiol, 164 (11): 1115-20.

Hillier S and Holmes KK (1999): Bacterial vaginosis. In: Holmes KK, et al., eds. Sexually transmitted diseases, $3^{\text {rd }}$ Ed. NewYork: McGrawHill: 563-86.

Irgens A, Kruger $\mathbf{K}$, Skorve $\mathbf{A H}$ and Irgens LM (1998): Reproductive outcome in offspring of parents occupationally exposed to lead in Norway. Am J Ind Med, 34(5): 431-7.

Jafari F, Eftekhar H, Pourreza $A$ and Mousavi J (2010): Socioeconomic and medical determinants of low birth weight in Iran: 20 years after establishment of a primary healthcare network. Public Health, 124: 153-8.

Julius SE (2008): Risk factors associated with low birth weight of neonates among pregnant women attending a referral hospital in northern Tanzania. Tanzania J Health Res, 10(1): 1-8.

Kind KL, Moore VM and Davies MJ (2006): Diet around conception and during pregnancy: Effects on fetal and neonatal outcomes. Reprod Biomed Online, 5: 532-41.

Klingenberg C, Olomi R, Oneko M, Sam N and Langeland $N$ (2003): Neonatal morbidity and mortality in a Tanzanian tertiary care referral hospital. Ann Paediatr, 23: 293-9.

Kolusari A, Kuroglu M, Yildizhan R, Adali E, Edirne $T$, Cebi A, Demir $H$ and Yoruk $I$ (2008): Catalase activity, serum trace element and heavy metal concentrations, and vitamin A, $\mathrm{D}$ and $\mathrm{E}$ levels in pre-eclampsia. J Int Med Res, 36: 1335-41.

Kramer MS (1987): Determinants of low birth weight: Methodological assessment and metaanalysis. Bull WHO, 65: 663-737.

Kusin JA, Kardjati S and Renqvist UH (1994): Maternal body mass index: The functional significance during reproduction. Euro $\mathrm{J}$ Clin Nutr, 48: 56-67.

Lamadrid-Figueroa H, Tellez-Rojo MM, Hernandez- Avila M, Trejo-Valdivia B, Solano-Gonzalez M, Mercado-Garcia A, Smith D, Hu H and Wright RO (2007): Association between the plasma/whole blood lead ratio and history of spontaneous abortion: A nested crosssectional study. BMC Pregnancy Childbirth, 7: 22-7.

Leary S, Fall C, Osmond C, Lovel H, Campbell D, Erikson J, Forrester T, Godfrey K, Hill J, Jie M, Law C, Newby R, Robinson S and Yajnik $C$ (2006): Geographical variation in relationships between parental body size and offspring phenotype at birth. Acta Obst Gynaecol Scand, 85: 1066-79. 
Lindheimer MD, Roberts JM, Cunningham FG and Chesley L (1999): Introduction, history, controversies and definitions. In: Chesley's hypertensive disorders in pregnancy (Lindheimer M, Roberts $\mathrm{J}$ and Cunningham F, eds.), 2nd Ed., 3-41. Stamford, CT: Appleton \& Lange, New York.

Lowry LW, et al. (1998): Effect of comprehensive care on pregnancy outcomes. Appl Nurs Res, 11(2): 55-61.

Mann LI, Tejani NA and Weiss RR (1974): Antenatal diagnosis and management of small for gestational age fetus. Am J Obst Gynecol, 120: 995-1004.

Mathule MS, Kennedy T, Gates G and Spicer MT (2005): Predictors of birth weight in healthy women attending a rural antenatal clinic. African J Food Agricult, Nutr Develop, 5: 1-18.

Mavalankar DV, Gray RH and Trivedi CR (1992): Risk factors for preterm and term low birth weight in Ahmedabad, India. Int $\mathrm{J}$ Epidemiol, 21: 263-72.

Meagher S (1993): Intrapartum stillbirth and suboptimal care. Aus J Fetal Med, 13(1): 8-11.

Mumbare SS, Maindarkar G, Darade R, Yenge S, Tolani MK and Patole $K$ (2012): Maternal risk factors associated with term low birth weight neonates: A matched-pair case control study. Indian Pediatr, 49(16): 25-8.

Naeye RL (1990): Maternal body weight and pregnancy outcome. Am J Clin Nutr, 52: 273-9.

NFHS-3 (National Family Health Survey-3, India 2005-06) (2007): International Institute of Population Sciences, 1: 225.

Pelletier D, Arimond M, Johnson FC, Liang E, Low J and Mvula P (1995): Maternal anthropometry predictors of IUGR and prematurity in Malawi Maternal and Child Nutrition study (OMS Supplement). Bull WHO, 73: 81-7.

Podja J and Kelley L (2000): Low birth eight. Administrative Committee on Coordination/Sub Committee on Nutrition, the UN Systems Forum for Nutrition, Nutrition policy: Paper No. 8.

Ragab HM, Sherif NA, Mahdy MM, Eltokhy HM and Saad AS (2001): Some aspects of reproductive performance among women aged 35 years or more. Egypt J Comm Med, 19(4): 112.

Renqvist R, Kardjati S and Kusi, JA (1994): Maternal body mass index: The functional significance during reproduction. Euro $\mathrm{J}$ Clin Nutr, 48: 3556-67.

Report the Task Force ACOG/AAP (2003): Neonatal encephalopathy and cerebral palsy: Defining the pathogenesis and pathophysiology.
Am College Obst Gynecol and Am Acad Pediatr, Washington, DC.

Roberts JM (1998): Pregnancy related hypertension. In: Maternal fetal medicine, (Creasy RK and Resnik R, eds.), 4th Ed, WB Saunders, Philadelphia.

Sahu MT, Agarwal A, Das V and Pandey A (2007): Impact of maternal body mass index on obstetric outcome. J Obst Gynecol Res, 33(5): 655-9.

Sharma MK, Kumar D, Huria A and Gupta P (2009): Maternal risk factors of low birth weight in Chandigarh, India. Internet $\mathrm{J}$ Health, 9. Available at http:// www. ispub. com/ journal/ the internet_journal of health/volume 9 numb er_1_12/ article/maternal-risk-factors-of-lowbirthweight-in-chandigarh-india.html.

Singh G, Chouhan R and Sidhu K (2009): Maternal factors for low birth weight babies. Med J Armed Forces India, 65: 10-2

Spinillo A, Capuzzi E, Piuzzi G, Ferrari A, Morales V and DeNrio M (1998): Risk for spontaneous preterm delivery and gestational weight gain patterns. Acta Obst Gynecol Scand, 77: 32-6.

Statistics Canada (2004): Low birth weight, 2001. Ottawa: Minister of Public Works and Government Services Canada.

Tema T (2006): Prevalence and determinants of low birth weight in Jima zone, South West Ethiopia. East Africa Med J, 83: 366-71.

UNAIDS (1999): Low birth weight. United Nations Administrative Committee on Coordination/Sub Committee on Nutrition. Nutrition policy: Paper No. 18.

UNICEF and WHO (United Nations Children's Fund and the World Health Organization) (2004): Low birthweight: Country, regional and global estimates, UNICEF and WHO, New York and Geneva.

Verma $V$ and Das KB (2000): Teenage primigravidae: A comparative study. Available athttp://www.hsph.harvard.eu/ Organisations/ healthnet/Sasia/forums/Nutrition/Nutr/S006.

Viengsakhone L, Yoshida Y, Harun-OrRashid $M$ and Sakamoto J (2010): Factors affecting low birth weight at four central hospitals in vientiane, Lao PDR. Nagoya J Med Sci, 72: 51-8.

Villar $J$ and Belizan $J$ (1982): The relative contribution of prematurity and fetal growth retardation to low birth weight in developing and developed societies. Am J Obst Gynecol, 143: 793-8.

Ward C, Lewis $S$ and Coleman $T$ (2007): Prevalence of maternal smoking and 
environmental tobacco smoke exposure during pregnancy and impact on birth weight: Retrospective study using Millennium Cohort. BMC Public Health, 7: 81-6

West WL, KtÃoeight EM, Edwards CH, Manning M, SpÃoerlock B, James H, Johnson AA, Jackson Cole ÃO, Westneyj Haziel Laryea OE, Jottestt $S$ and Westneyw LS (1994): Maternal low level lead and pregnancy outcomes. J Nutr, 124: 981S-6S.
WHO (World Health Organization) (1980): The incidence of low birth weight: A critical review of available information. World Health Statistics Quarterly, 33: 197-224.

Wilkinson D (1997): Reducing LBW mortality in developing countries. Seminar Engl, 161-5.

Wu G, Bazer FW, Wallace JM and Spencer TE (2006): Intrauterine growth retardation: Implications for the animal sciences. J Anim Sci, 84: 2316-37.

Table (1): Distribution of mother's with LBW neonates and mother's with NBW neonates according to sociodemographic risk factors.

\begin{tabular}{|c|c|c|c|c|c|}
\hline \multirow[t]{2}{*}{ Sociodemographic risk factors } & \multicolumn{2}{|c|}{$\begin{array}{l}\text { Mother's with } \\
\text { LBW neonates } \\
\quad(\mathbf{n}=\mathbf{2 1 8})\end{array}$} & \multicolumn{2}{|c|}{$\begin{array}{l}\text { Mother's with } \\
\text { NBW neonates } \\
\text { (n=262) }\end{array}$} & \multirow[t]{2}{*}{$\begin{array}{c}\text { OR }(95 \% \text { CI }) \\
\text { OR }(95 \% \text { ECL) }\end{array}$} \\
\hline & No. & $\%$ & No. & $\%$ & \\
\hline $\begin{array}{l}\text { Educational status: } \\
\text { Illiterate, read and write } \\
\text { Elementary } \\
\text { Secondary and university }\end{array}$ & $\begin{array}{l}107 \\
82 \\
29\end{array}$ & $\begin{array}{l}49.1 \\
37.6 \\
13.3\end{array}$ & $\begin{array}{c}93 \\
118 \\
51\end{array}$ & $\begin{array}{l}35.5 \\
45.0 \\
19.5\end{array}$ & $\begin{array}{l}1.75(1.19-2.57) \\
0.74(0.50-1.08) \\
0.63(0.37-1.07)\end{array}$ \\
\hline $\begin{array}{l}\text { Occupational status: } \\
\text { House wife } \\
\text { Unskilled (hard work) } \\
\text { Semi-skilled \& skilled } \\
\text { Professional }\end{array}$ & $\begin{array}{c}121 \\
74 \\
17 \\
6\end{array}$ & $\begin{array}{r}55.5 \\
33.9 \\
7.8 \\
2.8 \\
\end{array}$ & $\begin{array}{c}149 \\
63 \\
36 \\
14\end{array}$ & $\begin{array}{c}56.9 \\
24.1 \\
13.7 \\
5.3 \\
\end{array}$ & $\begin{array}{c}0.95(0.65-1.38) \\
1.62(1.07-2.47) \\
0.53(0.28-1.01) \\
0.50(0.16-1.42)^{*} \\
\end{array}$ \\
\hline $\begin{array}{l}\text { Social level: } \\
\text { Low } \\
\text { Middle } \\
\text { High } \\
\end{array}$ & $\begin{array}{c}118 \\
78 \\
22 \\
\end{array}$ & $\begin{array}{l}54.1 \\
35.8 \\
10.1\end{array}$ & $\begin{array}{l}113 \\
104 \\
45\end{array}$ & $\begin{array}{l}43.1 \\
39.7 \\
17.2\end{array}$ & $\begin{array}{l}1.56(1.07-2.27) \\
0.85(0.57-1.25) \\
0.54(0.30-0.96)\end{array}$ \\
\hline $\begin{array}{l}\text { Husband availability (social support): } \\
\text { Available } \\
\text { Not available }\end{array}$ & $\begin{array}{c}156 \\
62 \\
\end{array}$ & $\begin{array}{l}71.6 \\
28.4 \\
\end{array}$ & $\begin{array}{c}222 \\
40\end{array}$ & $\begin{array}{l}84.7 \\
15.3 \\
\end{array}$ & $\begin{array}{l}0.45(0.28-0.73) \\
2.21(1.38-3.54)\end{array}$ \\
\hline $\begin{array}{l}\text { Residence: } \\
\text { Rural } \\
\text { Urban }\end{array}$ & $\begin{array}{c}43 \\
175\end{array}$ & $\begin{array}{l}19.7 \\
80.3\end{array}$ & $\begin{array}{c}37 \\
225\end{array}$ & $\begin{array}{l}14.1 \\
85.9\end{array}$ & $\begin{array}{l}1.49(0.90-2.49) \\
0.67(0.40-1.11)\end{array}$ \\
\hline
\end{tabular}


Table (2): Distribution of mother's with LBW neonates and mother's with NBW neonates according to personal characteristic risk factors.

\begin{tabular}{|c|c|c|c|c|c|}
\hline \multirow[t]{2}{*}{ Personal characteristic risk factors } & \multicolumn{2}{|c|}{$\begin{array}{l}\text { Mother's with } \\
\text { LBW neonates } \\
\quad(\mathbf{n}=\mathbf{2 1 8})\end{array}$} & \multicolumn{2}{|c|}{$\begin{array}{l}\text { Mother's with } \\
\text { NBW neonates } \\
(\mathbf{n}=262)\end{array}$} & \multirow{2}{*}{$\begin{array}{c}\text { OR }(95 \% \text { CI }) \\
\text { OR }(95 \% \text { ECL)* }\end{array}$} \\
\hline & No. & $\%$ & No. & $\%$ & \\
\hline $\begin{array}{l}\text { Mother's age at marriage: } \\
\leq 18 \text { years } \\
>18 \text { years }\end{array}$ & $\begin{array}{c}43 \\
175 \\
\end{array}$ & $\begin{array}{l}19.7 \\
80.3\end{array}$ & $\begin{array}{c}27 \\
235 \\
\end{array}$ & $\begin{array}{l}10.3 \\
89.7\end{array}$ & $\begin{array}{l}2.14(1.23-3.72) \\
0.47(0.27-0.81) \\
\end{array}$ \\
\hline $\begin{array}{l}\text { Mother's height: } \\
\leq 145 \mathrm{~cm} \\
>145 \mathrm{~cm}\end{array}$ & $\begin{array}{c}52 \\
166 \\
\end{array}$ & $\begin{array}{l}23.9 \\
76.1 \\
\end{array}$ & $\begin{array}{c}23 \\
239 \\
\end{array}$ & $\begin{array}{c}8.8 \\
91.2 \\
\end{array}$ & $\begin{array}{l}3.26(1.86-5.72) \\
0.31(0.17-0.54)\end{array}$ \\
\hline $\begin{array}{l}\text { Mother's weight before/at early pregnancy: } \\
\leq 45 \mathrm{~kg} \\
>45 \mathrm{~kg}\end{array}$ & $\begin{array}{c}39 \\
179\end{array}$ & $\begin{array}{l}17.9 \\
82.1\end{array}$ & $\begin{array}{c}22 \\
240\end{array}$ & $\begin{array}{c}8.4 \\
91.6\end{array}$ & $\begin{array}{l}2.38(1.32-4.31) \\
0.42(0.23-0.76)\end{array}$ \\
\hline $\begin{array}{l}\text { Mother's weight at delivery: } \\
\leq 55 \mathrm{~kg} \\
>55 \mathrm{~kg}\end{array}$ & $\begin{array}{c}40 \\
178 \\
\end{array}$ & $\begin{array}{l}18.3 \\
81.7 \\
\end{array}$ & $\begin{array}{c}20 \\
242 \\
\end{array}$ & $\begin{array}{c}7.6 \\
92.4\end{array}$ & $\begin{array}{l}2.72(1.49-5.01) \\
0.37(0.20-0.67) \\
\end{array}$ \\
\hline $\begin{array}{l}\text { Mother's body mass index (BMI): } \\
\text { Malnutrition: }<18 \mathrm{~kg} / \mathrm{m}^{2} \\
\text { Underweight: } 18-<22 \mathrm{~kg} / \mathrm{m}^{2} \\
\text { Normal: } 22-<25 \mathrm{~kg} / \mathrm{m}^{2} \\
\text { Obese: } 25-30 \mathrm{~kg} / \mathrm{m}^{2}\end{array}$ & $\begin{array}{c}16 \\
27 \\
149 \\
26 \\
\end{array}$ & $\begin{array}{c}7.3 \\
12.4 \\
68.4 \\
11.9 \\
\end{array}$ & $\begin{array}{c}4 \\
13 \\
207 \\
38 \\
\end{array}$ & $\begin{array}{c}1.5 \\
5.0 \\
79.0 \\
14.5 \\
\end{array}$ & $\begin{array}{c}5.11(1.61-21.26)^{*} \\
2.71(1.30-5.71) \\
0.57(0.37-0.88) \\
0.80(0.45-1.41)\end{array}$ \\
\hline $\begin{array}{l}\text { History of consanguinity: } \\
\text { Yes } \\
\text { No }\end{array}$ & $\begin{array}{c}47 \\
171 \\
\end{array}$ & $\begin{array}{l}21.6 \\
78.4\end{array}$ & $\begin{array}{c}21 \\
241 \\
\end{array}$ & $\begin{array}{c}8.0 \\
92.0 \\
\end{array}$ & $\begin{array}{l}3.15(1.76-5.68) \\
0.32(0.18-0.57)\end{array}$ \\
\hline $\begin{array}{l}\text { History of previous LBW babies: } \\
\text { Yes } \\
\text { No }\end{array}$ & $\begin{array}{c}(\mathrm{n}=176) \\
13 \\
163\end{array}$ & $\begin{array}{c}7.4 \\
92.6\end{array}$ & $\begin{array}{c}(\mathrm{n}=211) \\
11 \\
200\end{array}$ & $\begin{array}{c}5.2 \\
94.8\end{array}$ & $\begin{array}{l}1.45(0.59-3.58) \\
0.69(0.28-1.69)\end{array}$ \\
\hline $\begin{array}{l}\text { History of previous abortion: } \\
\text { Yes } \\
\text { No }\end{array}$ & $\begin{array}{c}(\mathrm{n}=176) \\
29 \\
147 \\
\end{array}$ & $\begin{array}{l}16.5 \\
83.5 \\
\end{array}$ & $\begin{array}{c}(\mathrm{n}=211) \\
12 \\
199 \\
\end{array}$ & $\begin{array}{c}5.7 \\
94.3 \\
\end{array}$ & $\begin{array}{l}3.27(1.54-7.05) \\
0.31(0.14-0.65) \\
\end{array}$ \\
\hline $\begin{array}{l}\text { Maternal family history of LBW babies: } \\
\text { Yes } \\
\text { No }\end{array}$ & $\begin{array}{c}74 \\
144 \\
\end{array}$ & $\begin{array}{l}33.9 \\
66.1\end{array}$ & $\begin{array}{c}36 \\
226\end{array}$ & $\begin{array}{l}13.7 \\
86.3\end{array}$ & $\begin{array}{c}3.23(2.01-5.19) \\
0.31(0.19-.50)\end{array}$ \\
\hline
\end{tabular}


Essam A. El-Moselhy et al

Table (3): Distribution of mother's with LBW neonates and mother's with NBW neonates according to obstetric risk factors.

\begin{tabular}{|c|c|c|c|c|c|}
\hline \multirow[t]{2}{*}{ Personal and clinical risk factors } & \multicolumn{2}{|c|}{$\begin{array}{l}\text { Mother's with } \\
\text { LBW neonates } \\
\quad(\mathbf{n = 2 1 8})\end{array}$} & \multicolumn{2}{|c|}{$\begin{array}{l}\text { Mother's with } \\
\text { NBW neonates } \\
(\mathbf{n = 2 6 2 )}\end{array}$} & \multirow[t]{2}{*}{$\begin{array}{c}\text { OR }(95 \% \text { CI }) \\
\text { OR }(95 \% \text { ECL }) *\end{array}$} \\
\hline & No. & $\%$ & No. & $\%$ & \\
\hline $\begin{array}{l}\text { Mother's age at gestation: } \\
<20 \text { years } \\
\geq 20 \text { years }\end{array}$ & $\begin{array}{c}40 \\
178\end{array}$ & $\begin{array}{l}18.3 \\
81.7\end{array}$ & $\begin{array}{c}25 \\
237\end{array}$ & $\begin{array}{c}9.5 \\
90.5 \\
9\end{array}$ & $\begin{array}{l}2.13(1.21-3.77) \\
0.47(0.27-0.83)\end{array}$ \\
\hline $\begin{array}{l}\text { Parity: } \\
\text { Primi } \\
\text { Multi } \geq 3\end{array}$ & $\begin{array}{c}42 \\
176\end{array}$ & $\begin{array}{l}19.3 \\
80.7\end{array}$ & $\begin{array}{c}51 \\
211\end{array}$ & $\begin{array}{l}19.5 \\
80.5\end{array}$ & $\begin{array}{l}0.99(0.61-1.59) \\
1.01(0.63-1.64)\end{array}$ \\
\hline $\begin{array}{l}\text { Birth spacing: } \\
\quad \text { <2 Years } \\
\geq 2 \text { Years }\end{array}$ & $\begin{array}{c}45 \\
173\end{array}$ & $\begin{array}{l}20.6 \\
79.4\end{array}$ & $\begin{array}{c}22 \\
240\end{array}$ & $\begin{array}{c}8.4 \\
91.6\end{array}$ & $\begin{array}{l}2.84(1.59-5.08) \\
0.35(0.20-0.63)\end{array}$ \\
\hline $\begin{array}{l}\text { Multiple gestations: } \\
\text { Yes } \\
\text { No }\end{array}$ & $\begin{array}{c}52 \\
166\end{array}$ & $\begin{array}{l}23.9 \\
76.1\end{array}$ & $\begin{array}{c}11 \\
251\end{array}$ & $\begin{array}{c}4.2 \\
95.8\end{array}$ & $\begin{array}{l}7.15(3.49-14.98) \\
0.14(0.07-0.29)\end{array}$ \\
\hline $\begin{array}{l}\text { Bleeding at first or second trimester: } \\
\text { Yes } \\
\text { No }\end{array}$ & $\begin{array}{c}69 \\
149 \\
\end{array}$ & $\begin{array}{l}31.7 \\
68.3\end{array}$ & $\begin{array}{c}19 \\
243\end{array}$ & $\begin{array}{l}7.3 \\
92.7\end{array}$ & $\begin{array}{l}5.92(3.33-10.64) \\
0.17(0.09-0.30)\end{array}$ \\
\hline $\begin{array}{l}\text { Gestation age: } \\
\quad<37 \text { weeks } \\
\geq 37 \text { weeks }\end{array}$ & $\begin{array}{c}51 \\
167\end{array}$ & $\begin{array}{l}23.4 \\
76.6\end{array}$ & $\begin{array}{c}23 \\
239\end{array}$ & $\begin{array}{c}8.8 \\
91.2\end{array}$ & $\begin{array}{l}3.17(1.81-5.59) \\
0.32(0.18-0.55)\end{array}$ \\
\hline $\begin{array}{l}\text { Weight gain during pregnancy: } \\
\leq 6 \mathrm{~kg}\end{array}$ & 176 & 80.7 & 93 & 35.5 & $7.61(4.9-11.88)$ \\
\hline $\begin{array}{l}\text { Infant gender: } \\
\text { Female } \\
\text { Male }\end{array}$ & $\begin{array}{c}138 \\
80\end{array}$ & $\begin{array}{l}63.3 \\
36.7\end{array}$ & $\begin{array}{l}126 \\
136\end{array}$ & $\begin{array}{l}48.1 \\
51.9\end{array}$ & $\begin{array}{l}1.86(1.27-2.73) \\
0.54(0.37-0.79)\end{array}$ \\
\hline $\begin{array}{l}\text { Neonatal congenital malformations: } \\
\text { Present }\end{array}$ & $\begin{array}{c}(\mathrm{n}=270) \\
13\end{array}$ & 4.8 & $\begin{array}{c}(\mathrm{n}=270) \\
1\end{array}$ & 0.4 & $13.61(2.01-500.36) *$ \\
\hline $\begin{array}{l}\text { Complications during delivery: } \\
\text { Yes } \\
\text { No }\end{array}$ & $\begin{array}{c}42 \\
176\end{array}$ & $\begin{array}{l}19.3 \\
80.7\end{array}$ & $\begin{array}{c}15 \\
247\end{array}$ & $\begin{array}{c}5.7 \\
94.3\end{array}$ & $\begin{array}{l}3.93(2.04-7.67) \\
0.25(0.13-0.49)\end{array}$ \\
\hline
\end{tabular}


Table (4): Distribution of mother's with LBW neonates and mother's with NBW neonates according to life-style and health care behavioral risk factors.

\begin{tabular}{|c|c|c|c|c|c|}
\hline \multirow[t]{2}{*}{ Life-style and behavioral risk factors } & \multicolumn{2}{|c|}{$\begin{array}{c}\text { Mother's with LBW } \\
\text { neonates }(n=218)\end{array}$} & \multicolumn{2}{|c|}{$\begin{array}{c}\text { Mother's with NBW } \\
\text { neonates }(n=262)\end{array}$} & \multirow[t]{2}{*}{ OR $(95 \% \mathrm{CI})$} \\
\hline & No. & $\%$ & No. & $\%$ & \\
\hline \multicolumn{6}{|l|}{ Antenatal care (ANC): } \\
\hline No & 152 & 69.7 & 126 & 48.1 & $2.49(1.68-3.69)$ \\
\hline Yes: & 66 & 30.3 & 136 & 51.9 & $0.40(0.27-0.60)$ \\
\hline Regular ANC: & & & & & \\
\hline No ( $<4$ visits during pregnancy) & 47 & 21.6 & 36 & 13.7 & $1.73(1.04-2.86)$ \\
\hline Starting time of ANC: & & & & & \\
\hline Late at second or third trimester & 58 & 26.6 & 51 & 19.5 & $1.50(0.96-2.35)$ \\
\hline $\begin{array}{l}\text { Multivitamin intake: } \\
\text { No }\end{array}$ & 141 & 64.7 & 124 & 47.3 & $2.04(1.39-3.00)$ \\
\hline $\begin{array}{l}\text { Adequate healthy diet intake: } \\
\text { Inadequate healthy diet } \\
\text { Adequate healthy diet }\end{array}$ & $\begin{array}{c}139 \\
79\end{array}$ & $\begin{array}{l}63.8 \\
36.2\end{array}$ & $\begin{array}{l}103 \\
159\end{array}$ & $\begin{array}{l}39.3 \\
60.7\end{array}$ & $\begin{array}{l}2.72(1.84-4.01) \\
0.37(0.25-0.54)\end{array}$ \\
\hline $\begin{array}{l}\text { Physical hard activities: } \\
\text { Yes }\end{array}$ & 91 & 41.7 & 51 & 19.5 & $2.96(1.93-4.55)$ \\
\hline $\begin{array}{l}\text { Adequate rest times: } \\
\text { No }(<2 \mathrm{~h} \text { sleep/day, }<8 \mathrm{~h} \text { sleep/night })\end{array}$ & 78 & 35.8 & 47 & 17.9 & $2.55(1.64-3.97)$ \\
\hline $\begin{array}{l}\text { Exposure to cigarette smoke: } \\
\text { Yes }\end{array}$ & 167 & 76.6 & 124 & 47.3 & $3.64(2.41-5.53)$ \\
\hline $\begin{array}{l}\text { Living nearby heavy environmnental air pollution: } \\
\text { Yes }\end{array}$ & 178 & 81.7 & 126 & 48.1 & $4.8(3.09-7.48)$ \\
\hline
\end{tabular}

Table (5): Distribution of mother's with LBW neonates and mother's with NBW neonates according to medical, gynecological and obstetric risk factors.

\begin{tabular}{|c|c|c|c|c|c|}
\hline \multirow[t]{2}{*}{$\begin{array}{l}\text { Medical, gynecological and obstetric risk } \\
\text { factors }\end{array}$} & \multicolumn{2}{|c|}{$\begin{array}{c}\text { Mother's with } \\
\text { LBW neonates } \\
\quad(n=218)\end{array}$} & \multicolumn{2}{|c|}{$\begin{array}{c}\text { Mother's with } \\
\text { NBW neonates } \\
(n=262)\end{array}$} & \multirow[t]{2}{*}{$\begin{array}{l}\text { OR }(95 \% \text { CI }) \\
\text { OR }(95 \% \text { ECL })^{*}\end{array}$} \\
\hline & No. & $\%$ & No. & $\%$ & \\
\hline \multicolumn{6}{|c|}{ Medical } \\
\hline Anemia $(\mathrm{Hb}<10 \mathrm{~g} / \mathrm{dL})$ & 129 & 59.2 & 92 & 35.5 & $2.68(1.82-3.95)$ \\
\hline Diabetes mellitus & 4 & 1.8 & 11 & 4.2 & $0.43(0.10-1.47)^{*}$ \\
\hline Hypertension & 17 & 7.8 & 5 & 1.9 & $4.35(1.50-15.29) *$ \\
\hline Valvular heart disease & 11 & 5.1 & 6 & 2.3 & $2.27(0.75-7.59)^{*}$ \\
\hline History of recurrent chronic/specific infections & 32 & 14.7 & 9 & 3.4 & $4.84(2.15-11.19)$ \\
\hline Urinary tract infections & 37 & 17.0 & 16 & 3.4 & $3.14(1.63-6.11)$ \\
\hline \multicolumn{6}{|c|}{ Obstetric and gynecologic } \\
\hline Anorexia nervosa/stress & 14 & 6.4 & 5 & 1.9 & $3.53(1.17-12.69) *$ \\
\hline Hyperemesis gravidarum & 12 & 5.5 & 6 & 2.3 & $2.49(0.84-8.20)^{*}$ \\
\hline Oligo/polyhydramnios & 23 & 10.6 & 9 & 3.4 & $3.32(1.42-7.92)$ \\
\hline Vaginal infection/vaginosis & 27 & 12.4 & 12 & 4.6 & $2.95(1.39-6.34)$ \\
\hline Gestational diabetes & 3 & 1.4 & 10 & 3.8 & $0.35(0.06-1.39)$ \\
\hline Gestational hypertension & 28 & 12.8 & 11 & 4.2 & $3.36(1.56-7.39)$ \\
\hline PE/eclampsia & 19 & 8.7 & 9 & 3.4 & $2.68(1.12-6.56)$ \\
\hline
\end{tabular}


Table (6): Stepwise regression analysis of factors affecting low birth weight.

\begin{tabular}{|l|c|}
\hline \multicolumn{1}{|c|}{ Factors affecting low low birth weight } & $\begin{array}{c}\text { Partial } \\
\text { F-test }\end{array}$ \\
\hline Multiple gestations & 2.9 \\
Neonate congenital malformations & 2.7 \\
Weight gain during pregnancy $\leq 6 \mathrm{~kg}$ & 2.6 \\
Maternal malnutrition (severe underweight): BMI <18 kg/m² & 2.3 \\
Gestation age <37 weeks & 2.2 \\
Mother's weight before/at early pregnancy $\leq 45 \mathrm{~kg}$ & 2.2 \\
Maternal height < $145 \mathrm{~cm}$ & 2.1 \\
Exposure to tobacco smoke & 1.8 \\
No ANC utilization & 1.7 \\
Bleeding at first or second trimester & 1.5 \\
PE/eclampsia & 1.5 \\
Hypertension & 1.4 \\
Illiterate, read and write & 1.3 \\
Maternal family history of LBW babies & 1.3 \\
\hline
\end{tabular}
Adjusted $\mathrm{F}=1.3$ 


\section{المواليد قليلى الوزن: 1- عوامل الخطورة المتعلقه بالأم- دراسة الحاله الضابطه بالمستثفى فى

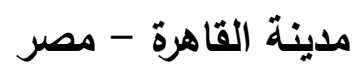 \\ عصام عبد المنعم المصيلحى* - ابراهيم سعد ندا*** - حامد عمر خليفة * - خضرة ابراهيم محمد \\ طب المجتمع***** - طب الصناعات و الصحة المهنية** - النساء والتوليد \\ كليات الطب - جامعة الأزهر}

تعتبر ولادة الأطفال قليلى الوزن مشكلة صحية هامة. وكان الهدف من هذه الدراسة تحديد عوامل خطورة هذه المشكلة وذلك من ناحية الأم. وقد استخدت نوعية دراسة الحالة الضابطة بالمستشفى لدراسة هذه المشكلة الصنال

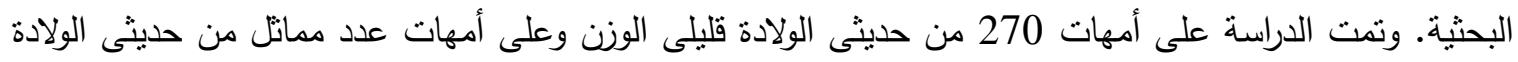

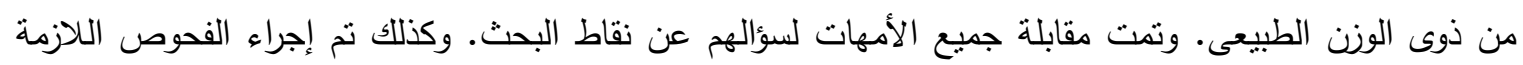

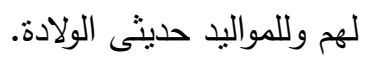

وقد بينت الدراسة أن التعليم المتنىى والأعمال غير الماهرة وعدم وجود الزوج بصفة دائمة من أهم عوامل

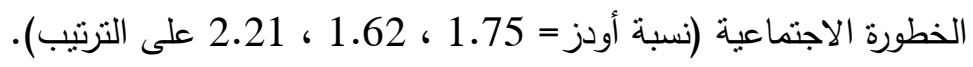

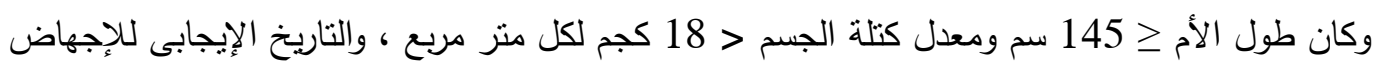

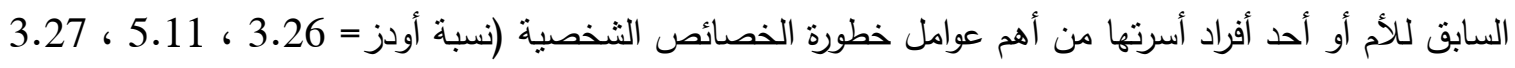
، 3.23 على التزتيب).

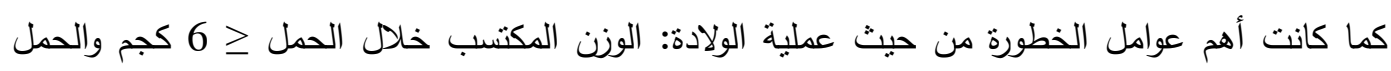

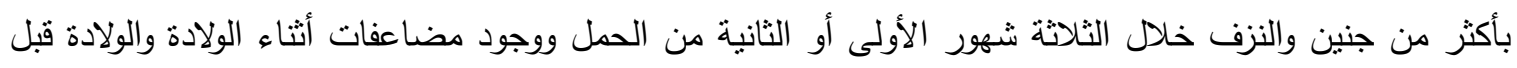
الأسبوع 37 والفترة بين الحملين أقل من سنتين (نسبة أودز= 7.61 ، 7.15 ، 5.92 ، 3.93 ، 3.17 ، 3.17 ، 2.84 على الترتيب).

وكان عدم الرعاية أثناء الحمل وقلة تتاول الغذاء الصحى والإجهاد البدنى والتعرض لدخان التبخ والمعيشة التهاء

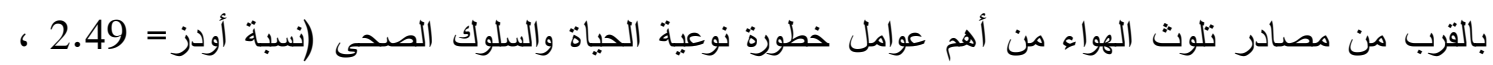
2.72، 2.96 ، 2.64 ، 3.64 ، 4.8 على الترتيب). وكانت أمراض نقص الهيموجلوبين وارتفاع ضغط الدم والالتهابات المنكررة من أهم عوامل الخطورة الطبية

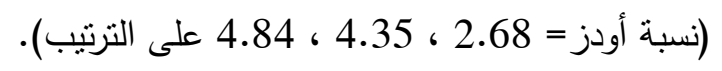

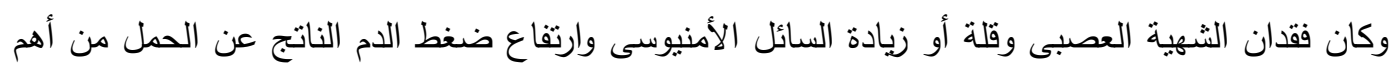

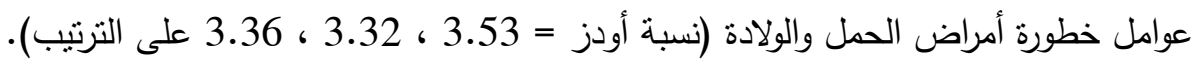

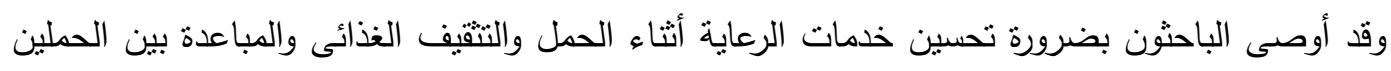

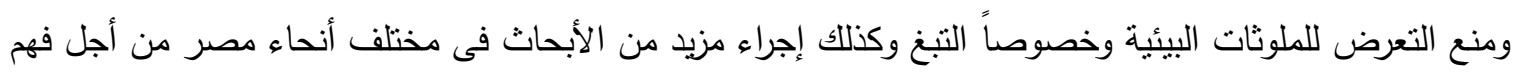
أفضل لوبائيات هذه المشكلة الصحية. 